\title{
In Vitro Propagation of Heliconia bihai (L.) L. from Zygotic Embryos
}

\author{
Cláudia Ulisses ${ }^{1,6}$, Gladys Flávia Melo-de-Pinna², Lilia Willadino ${ }^{3}$, Cynthia Cavalcanti de Albuquerque ${ }^{4}$ \\ e Terezinha Rangel Camara ${ }^{5}$
}

Recebido em 18/08/2008. Aceito em 2/09/2009

\begin{abstract}
RESUMO - (Propagação In vitro de Heliconia bihai (L.) L. provenientes de embriões zigóticos). Inicialmente os embriões procedentes de frutos imaturos e maduros de Heliconia bihai (L.) L. cv. Lobster Claw Two foram avaliados quanto à morfologia interna. Os embriões maduros foram inoculados em meio MS (1/2MS e MS completo) e $\mathrm{GA}_{3}\left(0,2,5\right.$ e 5,0 $\left.\mathrm{mg} \mathrm{L}^{-1}\right)$, utilizando sacarose ou glucose. Posteriormente, as plantas obtidas foram transferidas para meio 1/2MS acrescido de 0 ou $2.5 \mathrm{mg} \mathrm{L}^{-1}$ de BAP e aos 30 e 45 dias após a inoculação, avaliou-se a formação de gemas laterais. Aos 45 dias avaliou-se a variabilidade genética dessas plantas através da análise isoenzimática. Ao avaliar a morfologia interna observou-se que os embriões maduros apresentaram estádios de diferenciação superior aos embriões imaturos. Na fase de conversão do embrião em planta, observou-se que $85 \%$ dos embriões inoculados desenvolveram em plantas quando cultivados em meio $1 / 2 \mathrm{MS}$ com sacarose, contrastando com $41 \%$ cultivados no mesmo meio nutritivo acrescido de glucose. Na fase de multiplicação, as plantas cultivadas em meio $1 / 2 \mathrm{MS}$ acrescido de $2.5 \mathrm{mg} \mathrm{L}^{-1}$ de BAP apresentaram maior formação de gemas laterais. A análise isoenzimática apresentou diferença na intensidade de coloração e migração de algumas bandas. Esse comportamento pode estar associado com a diferença fisiológica relacionada à idade entre a planta mãe e as plantas provenientes do cultivo de embrião in vitro.

Palavras-chaves: carboidratos, cultivo de embrião, histologia, isoenzimas, micropropagação
\end{abstract}

ABSTRACT - (In vitro Propagation of Heliconia bihai (L.) L. from Zygotic Embryos). The internal morphology of embryos from immature and mature fruits of Heliconia bihai (L.) L. cv. Lobster Claw Two was examined. Embryos were inoculated into MS media (full MS and $1 / 2 \mathrm{MS})$ and GA $_{3}(0,2.5$ and $5 \mathrm{mg} \mathrm{L}^{-1}$ ) with either sucrose or glucose. These plantlets were then replicated and transferred to MS medium (full MS or $1 / 2 \mathrm{MS}$ ) with 0 or $2.5 \mathrm{mg} \mathrm{L}^{-1} \mathrm{BAP}$ and their multiplication was evaluated 30 and 45 days after inoculation. The genetic variability of the multiplied plants was estimated using isoenzyme analyses. The internal morphology of the mature embryos revealed their tissues to be in more advanced stages of differentiation than immature embryos. In the conversion phase, $85 \%$ of the inoculated embryos developed into plants in the $1 / 2 \mathrm{MS}$ medium with sucrose, in contrast to only $41 \%$ of the embryos that were cultivated with glucose. In the multiplication phase, plants cultivated in $1 / 2 \mathrm{MS}$ medium with $2.5 \mathrm{mg} \mathrm{L}^{-1} \mathrm{BAP}$ demonstrated more buds. Isoenzyme analyses showed pattern changes in terms of the color intensity and the migration of some of the bands. These results may be associated with differences in the ages of the mother plants and of the plantlets obtained in vitro.

Key words: carbohydrates, embryo culture, histology, isoenzymes, micropropagation

\section{Introduction}

Both national and international markets for decorative flowers and plants have become interested in providing new and different products to consumers, especially tropical species of the family Heliconiaceae (Order Zingiberales) (IBRAFLOR 2001). The genus Heliconia comprises approximately 250 species, the majority being native to the tropical regions of the American continent (Criley 1989). The plants of this genus possess rhizomes, are herbaceous, erect, and vary in height from 0.5 to $10 \mathrm{~m}$. The species Heliconia bihai (L.) L. cv. Lobster Claw Two is one of the most commercially important heliconias because of its erect inflorescence with strong orange-colored bracts having greenish borders and white fruits that become bluish when mature (Paiva 1998).

This species is vegetatively propagated for commercial purposes, but this technique promotes the dissemination of phytopathogens that can persist in plantings for many generations. In vitro culture has become popular in decorative horticulture as it allows rapid multiplication and reproduction of pathogen-eradicated plants (Chu 1985; Sato et al. 1999).

The in vitro establishment of heliconia shoots tips is frequently jeopardized by endophytic contaminants (Nathan et al. 1992; Atehortua et al. 1999; Dias \& Rodrigues 2001), making it important to develop techniques that can make micropropagation a more viable alternative. In view of the problem of endophytic contamination in heliconia shoots tips, zygotic embryos offer great promise as alternative sources of explants for in vitro clonal propagation due to their high regenerative potential and to the fact that they derive from a sterile environment within the ovary walls. However, interspecific crossing within heliconia does not seem to be very common due to factors such as the close association of specific pollinators with a given species, the existence of physiological barriers and the high species specificity of most of their pollen grains (Criley \& Broschat 1992).

The present work evaluated culture media with different salt concentrations, carbohydrate sources and growth regulator levels that could maximize in vitro zygotic embryo culture and subsequent in vitro clonal propagation of $H$. bihai (L.) L. cv. Lobster Claw Two.

\section{Material and methods}

Inflorescences of Heliconia bihai cv. Lobster Claw Two were harvest from a commercial producer in Paulista (07 $56^{\prime} 27^{\prime \prime} \mathrm{S}, 34^{\circ} 52^{\prime} 23^{\prime \prime} \mathrm{W}$ and 13 $\mathrm{m}$ altitude), Brazil. The fruits were detached and cleaned in the laboratory before removing the seeds.

\footnotetext{
1 Universidade Federal Rural de Pernambuco, Unidade Acadêmica de Garanhuns (UAG), Garanhuns, PE, Brasil

2 Universidade de São Paulo, Instituto de Biociências, Departamento de Botânica,, São Paulo, SP, Brasil

3 Universidade Federal Rural de Pernambuco, Departamento de Biologia, Recife, PE, Brasil

4 Universidade Estadual do Rio Grande do Norte, Departamento de Biologia, Mossoró, RN, Brasil

5 Universidade Federal Rural de Pernambuco, Departamento de Química, Recife, PE, Brasil

6 Autor para correspondência: claudia@nlink.com.br
} 
Analysis of the internal morphology of the zygotic embryo - Zygotic embryos derived from immature and mature fruits of $H$. bihai. were removed from the seeds, dehydrated, infiltrated using automatic histo-technical equipment and embedded in paraffin. 4-6 $\mu \mathrm{m}$ sections were subsequently cut on an automatic rotary microtome, the paraffin removed, and the sections were stained with hematoxylin and eosin (Johansen 1940).

Zygotic embryos culture - Fruits of $H$. bihai were collected from mother plants in both immature and mature developmental states and surface sterilized by immersion in $70 \%(\mathrm{v} / \mathrm{v})$ alcohol for one minute in a laminar flow chamber, followed by two immersions of 15 minutes each in a calcium hypochlorite solution (3\% solution containing three drops of $20 \%$ tween, for 20 minutes and then a $1.5 \%$ solution also containing tween). Fruits were then rinsed three times with sterile distilled water. Immediately after disinfection, the pericarps were extracted from the fruits using forceps and scalpels; the radicule region of the seed was then squeezed (using a pair of pliers) to force out the embryo. The embryos of both immature and mature fruits were inoculated into MS medium (Murashige \& Skoog 1962) (at full or half strength) supplemented with gibberellic acid at $0,2.5$ and $5.0 \mathrm{mg}$ $\mathrm{L}^{-1}$, plus either of two carbohydrates sources (sucrose or glucose) at $30 \mathrm{~g}$ $\mathrm{L}^{-1}$ and $2.0 \mathrm{~g} \mathrm{~L}^{-1}$ of Phytagel ${ }^{\mathbb{1}}$. Test tubes $(2.5 \times 15 \mathrm{~cm})$ containing $10 \mathrm{ml}$ of nutritional medium were used and $\mathrm{pH}$ of the nutritional medium was adjusted to 5.8 before autoclaving at $121{ }^{\circ} \mathrm{C}$ for 20 minutes. All possible combinations of salts, $\mathrm{GA}_{3}$ and carbohydrate sources were tested, with 10 repetitions per treatment.

Developing embryos were kept in the dark for eight days after inoculation to avoid excessive oxidation, and were subsequently cultured under a 16 hour photoperiod for 52 days with a luminosity of $50 \mu \mathrm{mols}$ $\mathrm{m}^{-2} \mathrm{~s}^{-1}$. During the incubation period the temperature of the growth room was maintained at $25^{ \pm} 2^{\circ} \mathrm{C}$.

Qualitative evaluations were made of explant development 15 days and 30 days after inoculation, and at 60 days the development of the aerial portions of the plantlets (leaf length and number) and the number of roots were recorded. The variables analyzed at 60 days were normalized by the transformation $\sqrt{x+0,5}$ for two-way variance analysis. Comparison of their means was performed using the Tukey Test at a $5 \%$ probability level.

Shoot multiplication - The shoot tips of plantlets derived from zygotic embryos from mature fruits were cut to produce propagation units approximately $1 \mathrm{~cm}$ long. The tips were then transferred to full or half strength MS medium with or without $2.5 \mathrm{mg} \mathrm{L}^{-1}$ of the growth regulator BAP (6-benzylaminopurine). The test tubes containing these shoot tips were kept in a growth chamber at $25^{+} 2^{\circ} \mathrm{C}$ with a 16 hour photoperiod and

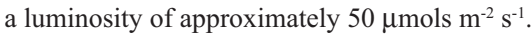

Evaluations were made 30 and 45 days after inoculation to determine the numbers and the sizes of shoots formed from the initial shoot-tip explant, and the total height of the new plants. The data was normalized using the $\sqrt{x+0,5}$ transformation for variance analysis, and means were compared using the Tukey Test at a 5\% probability level.

At the end of the multiplication phase, plants (approximately $5 \mathrm{~cm}$ tall) were acclimatized in disposable plastic cups $(250 \mathrm{~mL})$ containing a commercial substrate (Golden Mix) and were kept in a screened room with daily watering (in quantities sufficient to attain field capacity) for 60 days. Every two weeks the plants were watered with $100 \mathrm{~mL}$ of a nutrient solution containing $742.86 \mathrm{mg} \mathrm{L}^{-1}$ of soluble fertilizer (Kristalon ${ }^{\circledR}-3 \% \mathrm{~N} ; 11 \% \mathrm{P}_{2} \mathrm{O}_{5}$; $38 \% \mathrm{~K}_{2} \mathrm{O} ; 4 \% \mathrm{MgO} ; 11 \% \mathrm{~S} ; 0.025 \% \mathrm{~B} ; 0.004 \% \mathrm{Mo} ; 0.01 \% \mathrm{Cu}-\mathrm{EDTA}$; $0.025 \% \mathrm{Zn}$-EDTA, $0.07 \% \mathrm{Fe}$-EDTA and $0.04 \% \mathrm{Mn}$-EDTA), and $840 \mathrm{mg}$ $\mathrm{L}^{-1}$ calcium nitrate [Viking Vessel $-15.5 \% \mathrm{~N}$ and $19 \% \mathrm{Ca}$ ]).

Isoenzyme analyses - Peroxidase (PO), esterase (EST), acid phosphatase (ACP), malate dehydrogenase (MDH), alcohol dehydrogenase (ADH), and glutamate oxaloacetate transaminase (GOT) were examined. Approximately $300 \mathrm{mg}$ of young leaf tissue derived from 10 plants cultured in vitro from zygotic embryos, as well as young leaf tissue from the original plant, were macerated individually in $1.5 \mathrm{~mL}$ of extraction solution buffer until totally homogenized. The extraction solution consisted of lithium borate and tris-citrate buffers with $600 \mathrm{mg}$ sucrose and $600 \mathrm{mg}$ PVP (polyvinylpirrolidone). The extracts were centrifuged at $12.000 \mathrm{rpm}$ for 10 minutes at $4^{\circ} \mathrm{C}$, and $10 \mu \mathrm{L}$ of the supernatant was then added to the gel wells of a horizontal discontinuous electrophoresis setup.

Polyacrilamide gels (\%) were prepared according to Scandalios (1969). Lithium borate buffer was used in the wells, and the gels were run at approximately $4^{\circ} \mathrm{C}$ until the leading band migrated $5 \mathrm{~cm}$ from the application point. A migration current of 9.0 volts. $\mathrm{cm}^{-1}$ was used. After electrophoretic separation, specific revelations of the proteins for each enzymatic system were performed. The revelation protocols were based on Poulik (1957) for PO and GOT, and Scandalios (1969) for EST, the ACP, ADH, and $\mathrm{MDH}$. Zimograms were subsequently prepared to evaluate the numbers and intensities of the isozyme bands in order to define the electrophoretic patterns of the samples.

\section{Results and discussion}

Immature fruits are characterized by a blue-colored epicarp, white mesocarp pulp, and very dark brown and hard seeds; mature fruits have a dark blue epicarp, white mesocarp, and very dark brown and hard seeds.

Evaluation of the internal morphology of the zygotic embryos - Analyses of the internal morphology of the zygotic embryos derived from immature fruits revealed the presence of an operculum, having a yellowish coloration, endosperm, and a shoot axis in the initial stages of differentiation (Fig. 1). The embryos from mature fruits did not have a visible operculum, but the process of shoot axis formation was in a more advanced stage, with procambium, a fundamental meristem and a protoderm, which will give rise to the vascular tissue, cortex and epidermis, respectively (Fig. 1).

Embryos derived from mature fruits demonstrated more advanced stages of differentiation while embryos derived from immature fruits lacked specific tissues such as the endosperm. The absence of an endosperm may hinder in vitro embryo development because younger embryos have more complex nutritional demands (Hu \& Ferreira 1998). Paiva et al. (2004) observed that the germination process in Strelitzia reginae is dependent on the cotyledon reserves of the mature embryo, regardless of the availability of external nutrients.

Zygotic embryo culture - embryos derived from mature fruits initiated differentiation 15 days after inoculation by forming shoots, while embryos derived from immature fruits did not initiate differentiation even after 60 days in culture. This dissimilarity is associated with the internal morphology of the immature embryos, which do not have the same tissue compliments as mature embryos, although they still retain their endosperm (Fig. 1) The immaturity of the embryo may impede its differentiation into a plantlet $(\mathrm{Hu}$ \& Ferreira 1998). Younger embryos normally require higher carbohydrate concentrations in the culture medium in order to germinate (Bridgen 1994).) However, reported that the physiological state of the fruits of Astrocaryum ulei influenced the germination rate of the zygotic embryos independent of the sucrose concentrations tested (Pereira et al. 2006).

Depending on the species, immature embryos may be stimulated to grow by growth regulators such as the gibberellins (Hu \& Ferreira 1998). In the present study, addition of gibberellic acid to the nutrient medium did not lead the immature embryos to differentiate into seedlings. The immature embryos from immature fruits of heliconia may be at a stage of differentiation that requires more complex medium to support their growth, like observed with orchid embryos (Martini et al. 2001). 

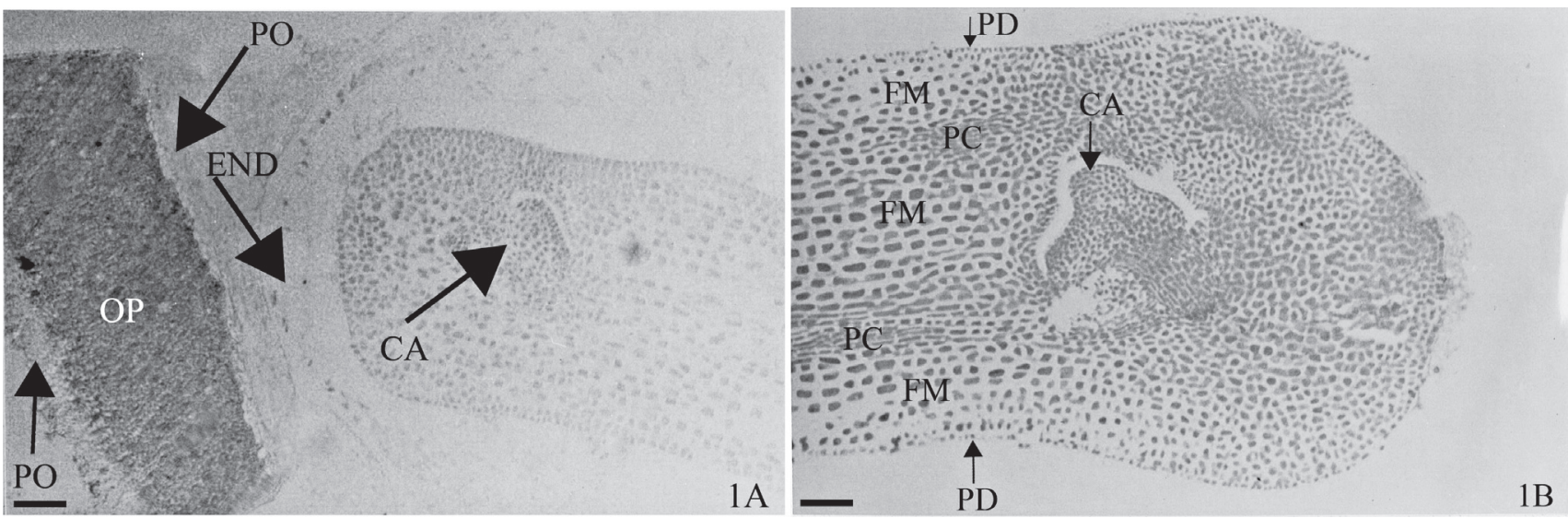

Figure 1. Longitudinal sections of zygotic embryos of Heliconia bihai (L.) L. cv. Lobster Claw Two: (1A) Zygotic embryo from an immature fruit, indicating the operculum (OP), operculum wall (OW), endosperm (END), and the initiation of the differentiation of the shoot tips (ST) $($ Bar $=1 \mathrm{~mm}) ;(1 \mathbf{B})$ Zygotic embryo from a mature fruit showing the shoot tip region $(\mathrm{ST})$, protoderm $(\mathrm{PD})$, fundamental meristem $(\mathrm{FM})$, and procambrium $(\mathrm{PC})(\mathrm{Bar}=1 \mathrm{~mm})$.

Most of embryos differentiated into seedling approximately 30 days after inoculation. This represents a relatively short period of time in comparison with Avena sativa L., which only achieved full development after 12 months in culture (Lamb et al. 2002). The formation of shoots and roots in embryos of zygotic origin of the orchid Gongora quinquenervis was only observed 180 days after inoculation into MS medium in the absence of growth regulators (Martini et al. 2001). Fully $85 \%$ of the embryos derived from mature fruits cultivated on media containing sucrose formed normal plants sixty days after inoculation, whereas only $41 \%$ of the embryos cultivated in glucosecontaining media differentiated into plantlets. Plants cultivated in the sucrose-containing medium demonstrated vigorous dark-green leaves, while those cultivated in glucose medium were poorly developed and demonstrated necrotic regions after 60 days (Fig. 2). Similar results were observed with Persea americana Mill (Llano Agudelo et al. 1995) and with Euterpe oleracea Mart (Ledo et al. 2001), with differentiation rates of $85 \%$ and $84 \%$ respectively in MS medium with sucrose. Gollagunta et al. (2004) likewise observed that sucrose favored in vitro development of Hosta

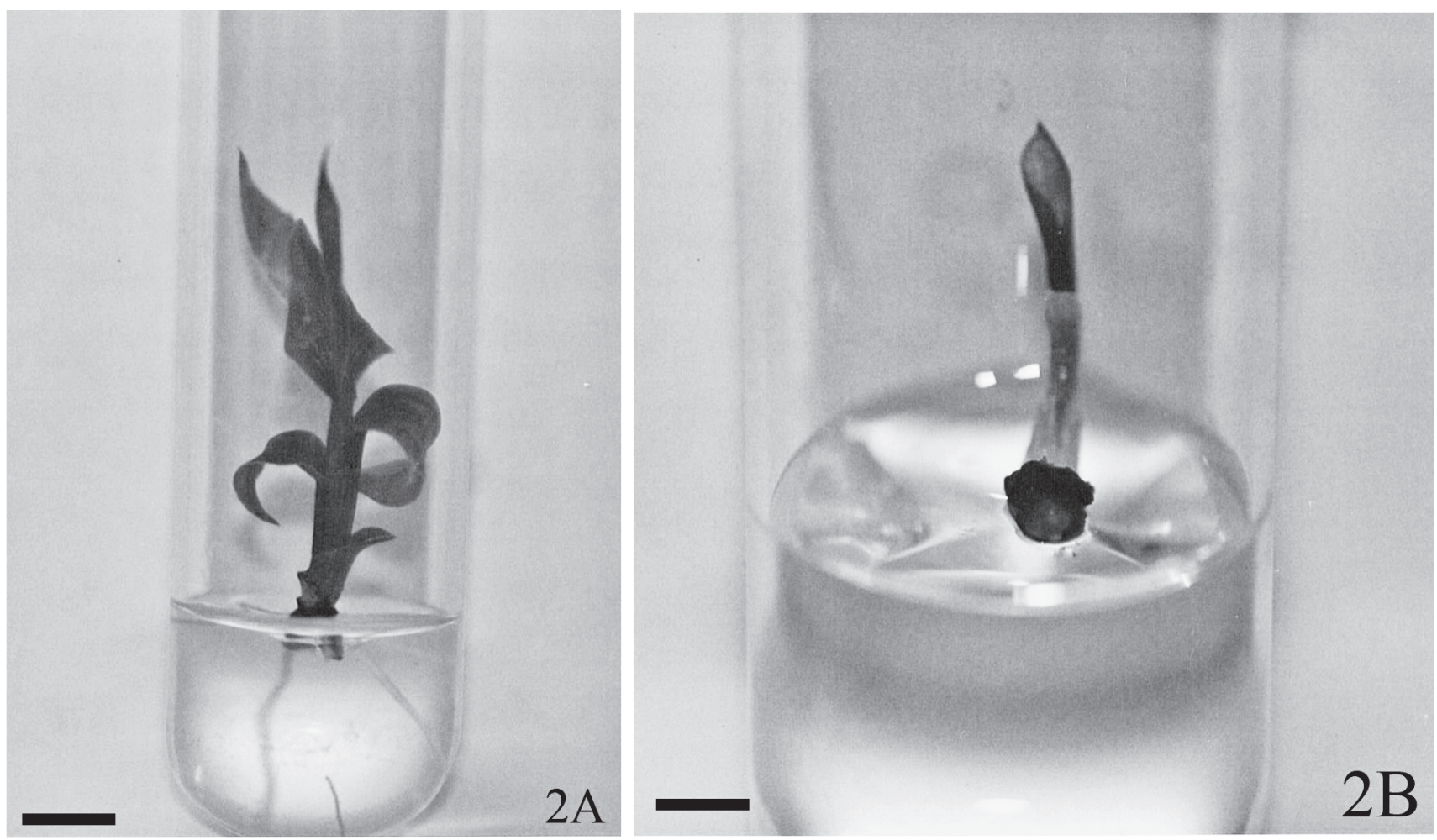

Figure 2. Plantlets of Heliconia bihai (L.) L. cv. Lobster Claw Two resulting from the in vitro culture of zygotic embryos 60 days after inoculation: (2A) Plant cultivated in $1 / 2$ MS medium with $30 \mathrm{~g} \mathrm{~L}^{-1}$ sucrose $(\mathrm{Bar}=1.19 \mathrm{~cm})$; (2B) Plant cultivated in $1 / 2$ MS medium with $30 \mathrm{~g} \mathrm{~L}^{-1}$ glucose $(B a r=0.83 \mathrm{~cm})$. 
tokudama. Embryo differentiation in the presence of glucose was inferior to that registered for sucrose, both in terms of the numbers of differentiated embryos and the general aspect of the plantlets.

Plantlets obtained from zygotic embryos derived from mature fruits demonstrated better development in the $1 / 2 \mathrm{MS}$ medium than in full-strength medium, regardless the carbohydrate source tested. The best shoot development, as measured by height, leaf number, and root development (Tab. 1) was observed only when sucrose was supplied. Lédo et al. (2007) observed that zygotic embryos isolated from the mature fruits of Cocus nucifera L. also differentiated into complete and normal plants when sucrose was used as the in vitro carbohydrate nutrient source in the nutrient medium.

Carbohydrates play an important role in the maintenance of an adequate osmotic balance in the growth medium as well as in the promotion of embryo growth. Sucrose has been widely used as an energy source because explants cultivated in vitro are heterotrophic and depend on external energy and carbon sources (Hu \& Ferreira 1998). Rojas et al (1996) observed that the response of explants to a certain carbon source depends on the genetic disposition of the species. These authors observed that $75 \%$ of the seeds of Coffea arabica germinated 40 days after in vitro inoculation when sucrose or other carbon sources (lactose and glucose) were used, but only glucose promoted shoot development.

Gibberellins are linked to the activation of vegetative growth of plant embryos, to the weakening of the endosperm layer that surrounds the embryo and restricts its growth, and to the mobilization of endosperm energy reserves (Taiz \& Zeiger 2004). In the present work, the addition of $\mathrm{GA}_{3}$ to the glucose-containing media resulted in an increase in shoot height and the numbers of leaves and roots. Despite this stimulating effect of $\mathrm{GA}_{3}$ on the shoot tips and roots of plants cultivated with glucose, our results indicated that the presence of sucrose was more efficient overall at promoting growth, especially in the absence of this gibberellin. The presence of $\mathrm{GA}_{3}$ in the culture medium had an inhibitory effect on leaf number when used together with sucrose (Tab. 2), regardless of the MS salt concentration (Tab. 3). This observation reflects the physiological requirements of the explants, as mature (or nearly mature) excised embryos do not generally require supplementary growth regulators (Hu \& Ferreira 1998). In Euterpe oleracea Mart, for example, complete seedlings were formed from zygotic embryos in MS medium in the absence of growth regulators (Yokoo et al. 1992).

Considering all of the variables examined (shoot height, leaf and root numbers), MS medium at half concentration with $30 \mathrm{~g} \mathrm{~L}^{-1}$ sucrose, without any growth regulator, was the best culture medium for obtaining in vitro differentiation of zygotic embryos into plantlets.

Shoot multiplication - The presence of BA in $1 / 2$ MS medium promoted heliconia shoot multiplication. ANOVA indicated that the numbers of shoots and roots were simultaneously influenced by BA levels and MS strength. This was determined by significant BA levels versus MS strength interactions. The largest numbers of shoots were observed in media supplemented with $2.5 \mathrm{mg} \mathrm{L}^{-1} \mathrm{BA}$, while the highest numbers of roots were seen among shoots cultured without BA, using $1 / 2$ MS medium in both cases (Tab. 4). Shoot multiplication in some species of heliconia was induced by $5 \mathrm{mg} \mathrm{L}^{-1} \mathrm{BA}$ (Atehortua et al., 1999). Similar results were reported by Oliveira et al. (2001) with bananas (Musa sp.), with the highest multiplication rates being obtained in the presence of $4 \mathrm{mg}$ $\mathrm{L}^{-1} \mathrm{BA}$, with a mean of 2.65 plantlets per subculture. In the present work, the number of shoots produced was greatest after 45 days than after 30 days, 1.57 and 1.45 , respectively. Likewise, the greatest numbers of shoots of H. psittacorum were produced after 45 days of culture in full strength MS with $2.25 \mathrm{mg} \mathrm{L}^{-1}$ BA (Nathan et al., 1992).

The addition of BA increased shoot height regardless of MS media strength, and the low BA concentrations used in this work reduce the risk of producing somaclonal variations, since BA is one of the main agents of genotypic alteration (Smith, 1988). The results obtained in the present work may aid in reducing the costs of $i n$ vitro commercial production of cutting sections of $H$. bihai because of the smaller quantities of mineral salts and BA required.

The plantlets produced in treatments with $1 / 2 \mathrm{MS}$ and $2.5 \mathrm{mg} \mathrm{L}^{-1} \mathrm{BA}$ had radicular systems with fine as well as secondary roots. This is an important result because these secondary roots formed without the addition of specific rooting inductors, like auxins. Radicular systems having fine and short roots, which favor nutrient absorption and plant development are associated with high survival rates in the acclimatization phase (Grattapaglia \& Machado, 1998). The $95 \%$ survival rate of acclimatized heliconia plantlets achieved in the present study demonstrates that the irrigation, nutrition, and substrate conditions were satisfactory. Similar results were obtained by Nathan et al. (1992) in H. psittacorum, with a $90 \%$ survival rate of acclimatized plants. On the other hand, Rodrigues et al. (2005) obtained a high acclimatization rate $(95 \%)$ with heliconia plants that did not have secondary roots and that demonstrated root tissue necrosis. It is possible that the new roots developed by these acclimatized seedlings represented a residual effect of the auxin treatment $\left(0.1 \mathrm{mg} \mathrm{L}^{-1} \mathrm{IBA}\right)$ during in vitro culture.

Isoenzyme analyses - All of the plant material tested in the present study demonstrated consistent numbers of bands and electrophoretic mobility in the PO, EST, ACP, ADH and GOT isoenzyme systems, only showing alterations in the intensities of the band colors. Cathodic bands were only observed in the $\mathrm{PO}, \mathrm{MDH}$ and $\mathrm{ADH}$ systems. In the PO system, cathodic bands demonstrated weak coloring intensity, while in the MDH and ADH systems the cathodic bands were achromatic (Fig. 3, 4 and 5).

An inversion in the intensity of coloration the EST-1 and EST-2 bands and with the ACP-1 and the ACP-2 of the matrix plant (MP) in the esterase and phosphatase acid isoenzyme 
Table 1. Development of plants of Heliconia bihai (L.) L. cv. Lobster Claw Two from zygotic embryos derived from mature fruits after 60 days of in vitro culture with different carbohydrate sources and MS salt concentrations.

\begin{tabular}{cccccccc}
\hline \multirow{2}{*}{$\begin{array}{l}\text { Nutritional Medium / } \\
\text { Carbohydrate Source }\end{array}$} & \multicolumn{2}{c}{ Height $(\mathrm{cm})$} & \multicolumn{2}{c}{ Number of leaves } & \multicolumn{2}{c}{ Number of roots } \\
\cline { 2 - 7 } & $1 / 2 \mathrm{MS}$ & MS & $1 / 2 \mathrm{MS}$ & MS & $1 / 2 \mathrm{MS}$ & MS \\
\hline Sucrose & $1.48 \mathrm{aA}$ & $0.97 \mathrm{bA}$ & $1.63 \mathrm{aA}$ & $1.52 \mathrm{bA}$ & $3.87 \mathrm{aA}$ & $0.69 \mathrm{bA}$ \\
Glucose & $0.68 \mathrm{aB}$ & $0.09 \mathrm{bB}$ & $1.22 \mathrm{aB}$ & $1.00 \mathrm{bB}$ & $1.44 \mathrm{aB}$ & $0.00 \mathrm{bB}$ \\
\hline
\end{tabular}

Means followed by the same small letters within each line, and capital letters within each column, are not significantly different at a $5 \%$ probability level by the Tukey Test. Factor interaction was not significant.

Table 2. Development of plants of Heliconia bihai (L.) L. cv. Lobster Claw Two from zygotic embryos derived from mature fruits after 60 days of in vitro culture with different carbohydrate sources and varying concentrations of GA3 on MS medium.

\begin{tabular}{|c|c|c|c|c|c|c|}
\hline \multirow{2}{*}{$\begin{array}{l}\text { Nutritional Medium/ } \\
\text { Concentration of } \mathrm{GA}_{3} \\
\qquad\left(\mathrm{mg} \mathrm{L}^{-1}\right)\end{array}$} & \multicolumn{2}{|c|}{ Height $(\mathrm{cm})$} & \multicolumn{2}{|c|}{ Number of Leaves } & \multicolumn{2}{|c|}{ Number of roots } \\
\hline & Sucrose & Glucose & Sucrose & Glucose & Sucrose & Glucose \\
\hline 0 & $1.98 \mathrm{aA}$ & $0.15 \mathrm{bC}$ & $3.38 \mathrm{aA}$ & $1.15 \mathrm{bB}$ & $2.58 \mathrm{aA}$ & $0.15 \mathrm{bC}$ \\
\hline 2.5 & $0.78 \mathrm{aC}$ & $0.25 \mathrm{bB}$ & $1.00 \mathrm{aB}$ & $1.00 \mathrm{aC}$ & $2.06 \mathrm{aB}$ & $0.51 \mathrm{bB}$ \\
\hline 5.0 & $1.00 \mathrm{aB}$ & $0.75 \mathrm{bA}$ & $1.00 \mathrm{bB}$ & $1.18 \mathrm{aA}$ & $1.50 \mathrm{aC}$ & $1.30 \mathrm{bA}$ \\
\hline
\end{tabular}

Means followed by the same small letters within each line, and capital letters within each column, are not significantly different at a $5 \%$ probability level by the Tukey Test. Factor interaction was not significant.

Table 3. Development of plants of Heliconia bihai (L.) L. cv. Lobster Claw Two from zygotic embryos derived from mature fruits after 60 days of in vitro culture with different concentrations of GA3 and MS medium (salt concentrations).

\begin{tabular}{ccccccc}
\hline \multirow{2}{*}{$\begin{array}{c}\text { Nutritional Medium/ } \\
\begin{array}{c}\text { Concentration of GA } \\
\left(\mathrm{mg} \mathrm{L}^{-1}\right)\end{array}\end{array}$} & \multicolumn{2}{c}{ Height $(\mathrm{cm})$} & \multicolumn{2}{c}{ Number of Leaves } & \multicolumn{2}{c}{ Number of roots } \\
\cline { 2 - 7 } & $1 / 2 \mathrm{MS}$ & $\mathrm{MS}$ & $1 / 2 \mathrm{MS}$ & $\mathrm{MS}$ & $1 / 2 \mathrm{MS}$ & $\mathrm{MS}$ \\
\hline 0 & $1.17 \mathrm{aB}$ & $0.68 \mathrm{bA}$ & $2.28 \mathrm{aA}$ & $1.85 \mathrm{bA}$ & $1.80 \mathrm{aC}$ & $0.59 \mathrm{bA}$ \\
2.5 & $0.61 \mathrm{aC}$ & $0.40 \mathrm{bB}$ & $1.00 \mathrm{aC}$ & $1.00 \mathrm{aB}$ & $2.26 \mathrm{aB}$ & $0.39 \mathrm{bB}$ \\
5.0 & $1.46 \mathrm{aA}$ & $0.38 \mathrm{bC}$ & $1.18 \mathrm{aB}$ & $1.00 \mathrm{bB}$ & $3.70 \mathrm{aA}$ & $0.00 \mathrm{bC}$ \\
\hline
\end{tabular}

Means followed by the same small letters within each line, and capital letters within each column, are not significantly different at a $5 \%$ probability level by the Tukey Test. Factor interaction was not significant.

systems, for while the EST-1 and the ACP-1 bands showed strong coloration, the other bands in the other systems demonstrated less intense staining. The same situation was observed in EST-2 and ACP-2 bands as these also exhibited more intense staining than the other systems mentioned above (Fig. 3 and 4). This result may be associated with the age difference between the matrix plant and the plants obtained from the in vitro culture of embryos. In the malate dehydrogenase (MDH) system, the MDH-2 band was observed to advance, forming a $\mathrm{MDH}-3$ band in clones $\mathrm{C} 2$ and C4 (Fig. 4). Similar results were reported by Royo et al. (1994) and Sawazaki et al. (1996), who observed that only the GOT system of Vitis vinifera demonstrated band migration diversity, with some bands advancing or delaying in relation to the others. These same authors suggested that this diversity might only be associated with migration speed, as genetic crossings to confirm Mendelian inheritance were not carried out. However, Jarret \& Litz (1986) and Rani \& Raina (2000) reported that the presence or absence of bands significantly assists in genotype identification.

Isoenzyme systems are important biochemical tools for identifying interspecific hybrids and genetic variants as well as for detecting genetic alterations in plants as a consequence
Table 4. Shoot development of Heliconia bihai (L.) L. cv. Lobster Claw Two at 45 days during the multiplication phase.

\begin{tabular}{ccc}
\hline \multicolumn{3}{c}{ Numbers of shoots } \\
\hline Medium & $0 \mathrm{mg} \mathrm{L}^{-1} \mathrm{BA}$ & $2.5 \mathrm{mg} \mathrm{L}^{-1} \mathrm{BA}$ \\
\hline $\mathrm{MS}$ & $1.19 \mathrm{aB}$ & $1.64 \mathrm{BA}$ \\
$1 / 2 \mathrm{MS}$ & $1.21 \mathrm{aB}$ & $2.33 \mathrm{AA}$ \\
\hline \multicolumn{3}{c}{ SHOOT LENGTH $(\mathrm{CM})$} \\
\hline MS & $0.22 \mathrm{aB}$ \\
$1 / 2 \mathrm{MS}$ & $0.24 \mathrm{aB}$ & $0.60 \mathrm{AA}$ \\
\hline \multicolumn{3}{c}{ NuMBERS OF ROOTS } \\
\hline MS & $0.79 \mathrm{bA}$ \\
\hline $1 / 2 \mathrm{MS}$ & $0.82 \mathrm{aA}$ & $0.00 \mathrm{BB}$ \\
\hline
\end{tabular}

Means followed by different letters within each column differ among themselves at a $5 \%$ probability level by the Tukey Test.

of in vitro culturing, as reported for Lycopersicon esculentum (Evans et al. 1984), Solanum phureja (Pehu et al. 1986), Rubus idacus (Cousineau \& Dounelly 1989), Ipomoea batatas (Alves et al. 1994), Saccharum officinalis (Taylor et al. 1995), Musa sp. (Ulisses et al. 2002) and Ananas comosus (Feuser et al. 2003).

Although Freitas et al. (1995) were able to characterize clones of Malpighia glabra L. using only isoenzyme 


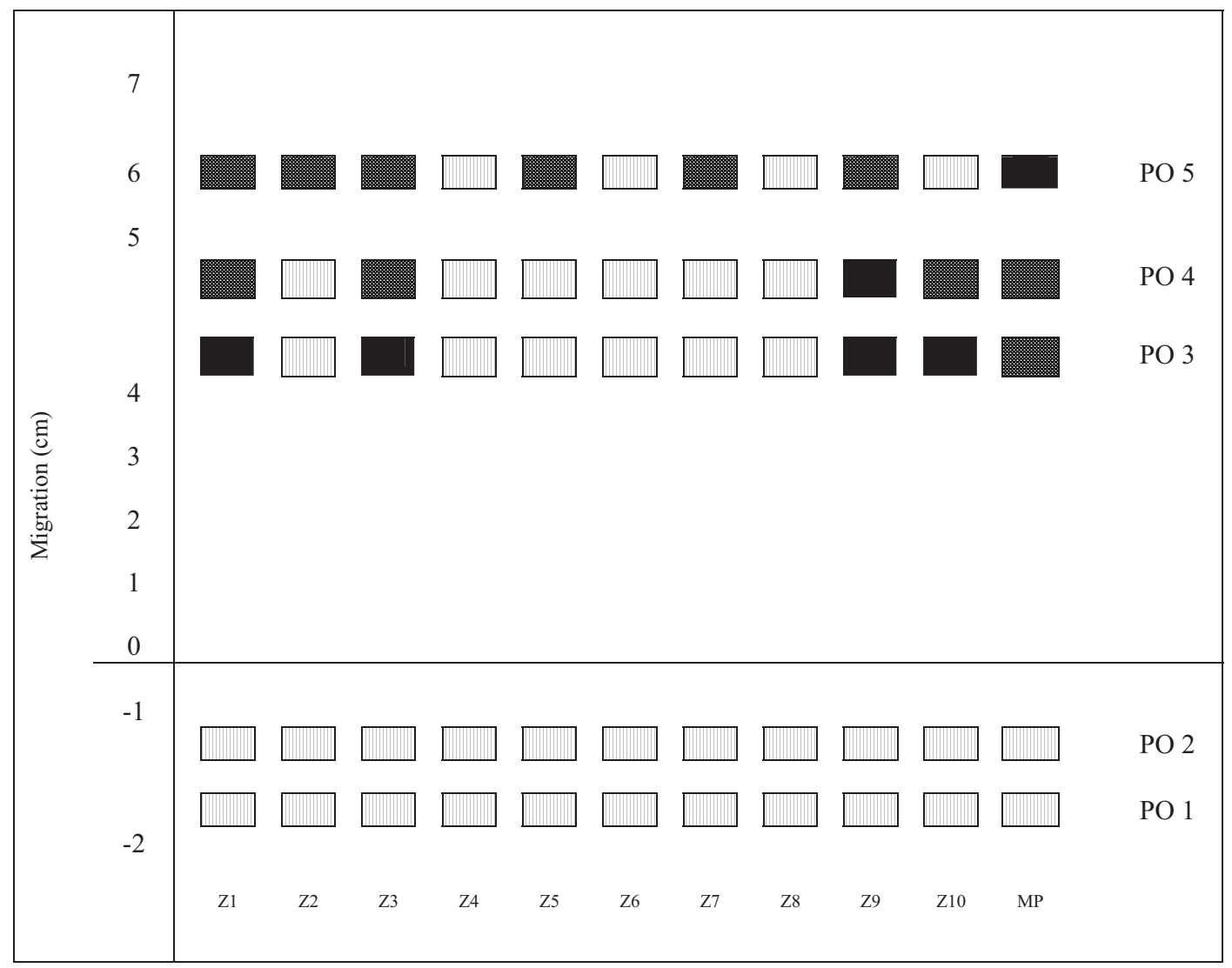

PEROXIDASE

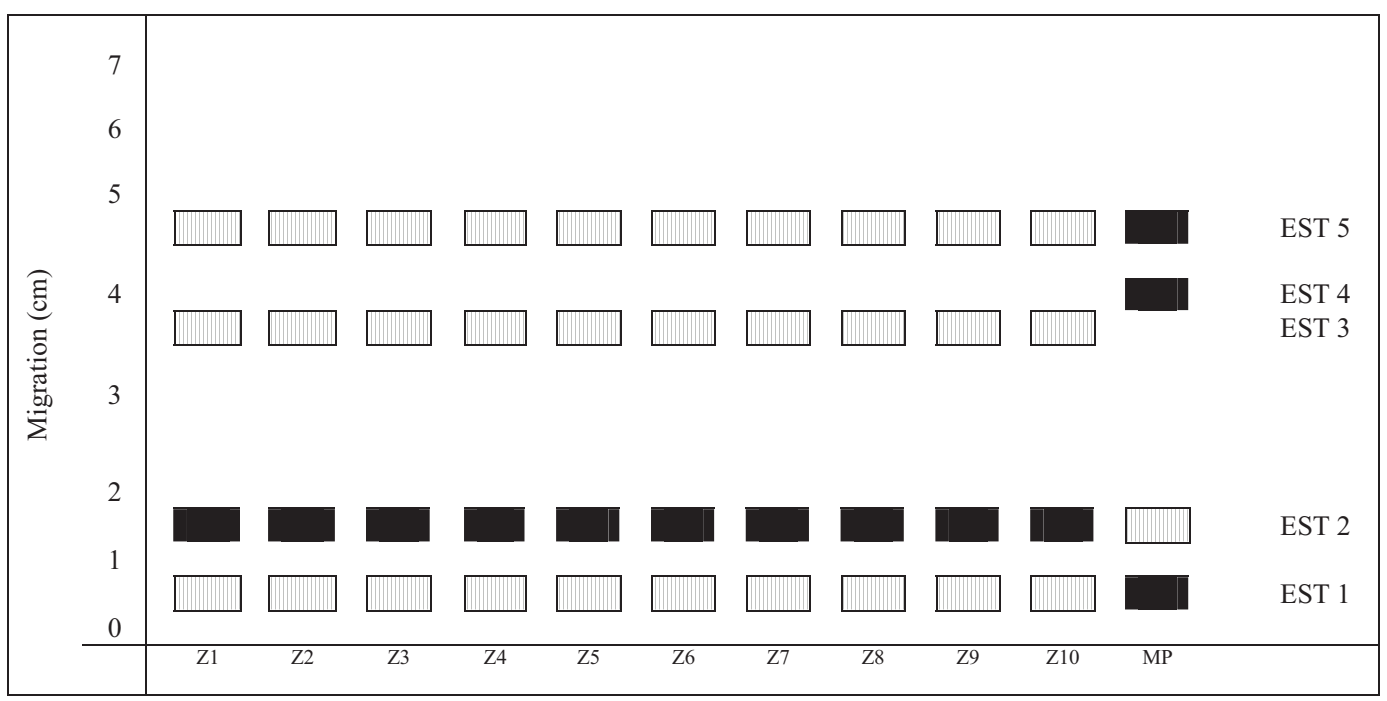

ESTERASE

Weak Band

Medium Band

Strong Band

Figure 3. Schematic representation of the zymograms of Peroxidase and Esterase isoenzyme systems from micropropagated plants derived from zygotic embryos (Z) and from the matrix plant (MP) of Heliconia bihai (L.) L. cv. Lobster Claw Two. 


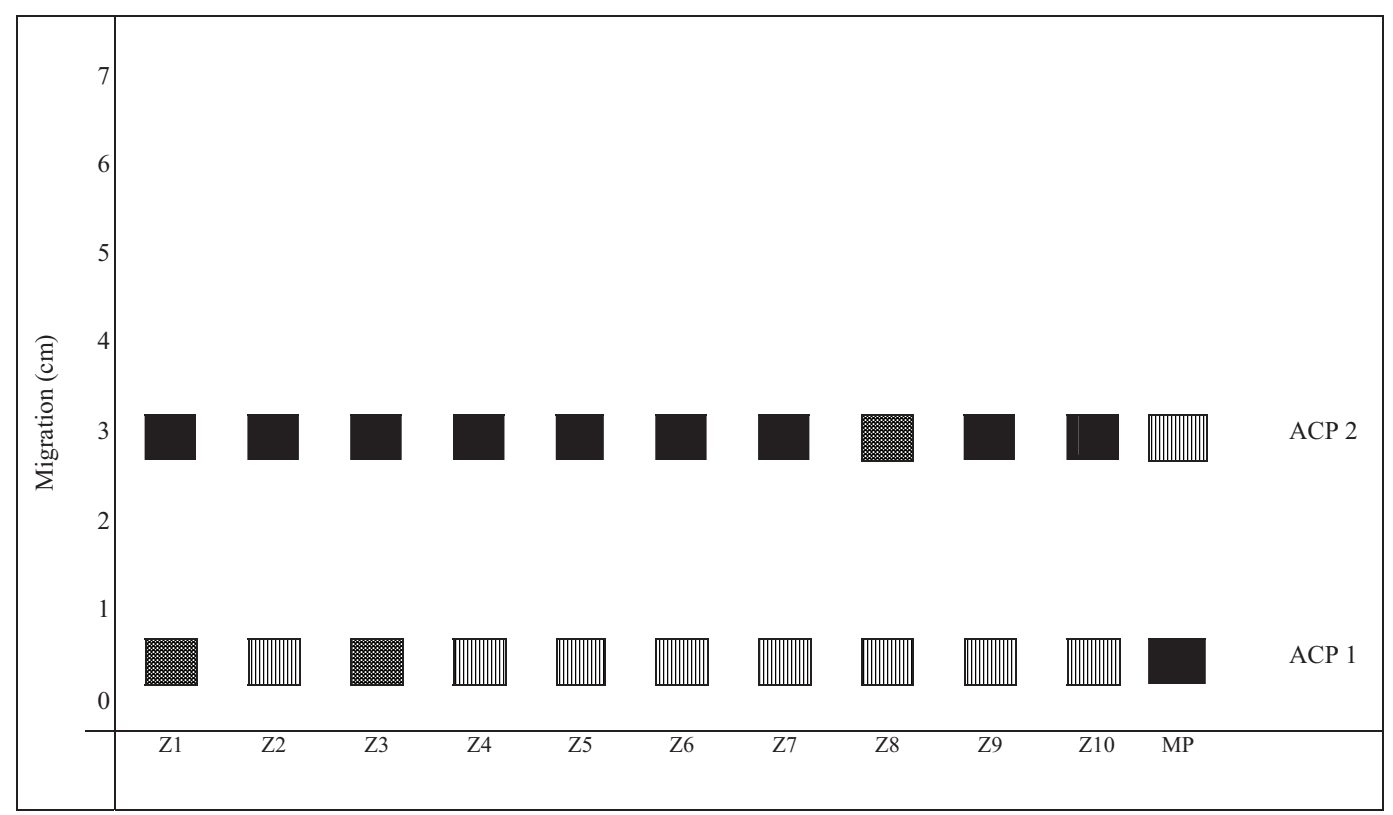

ACID PHOSPHATASE

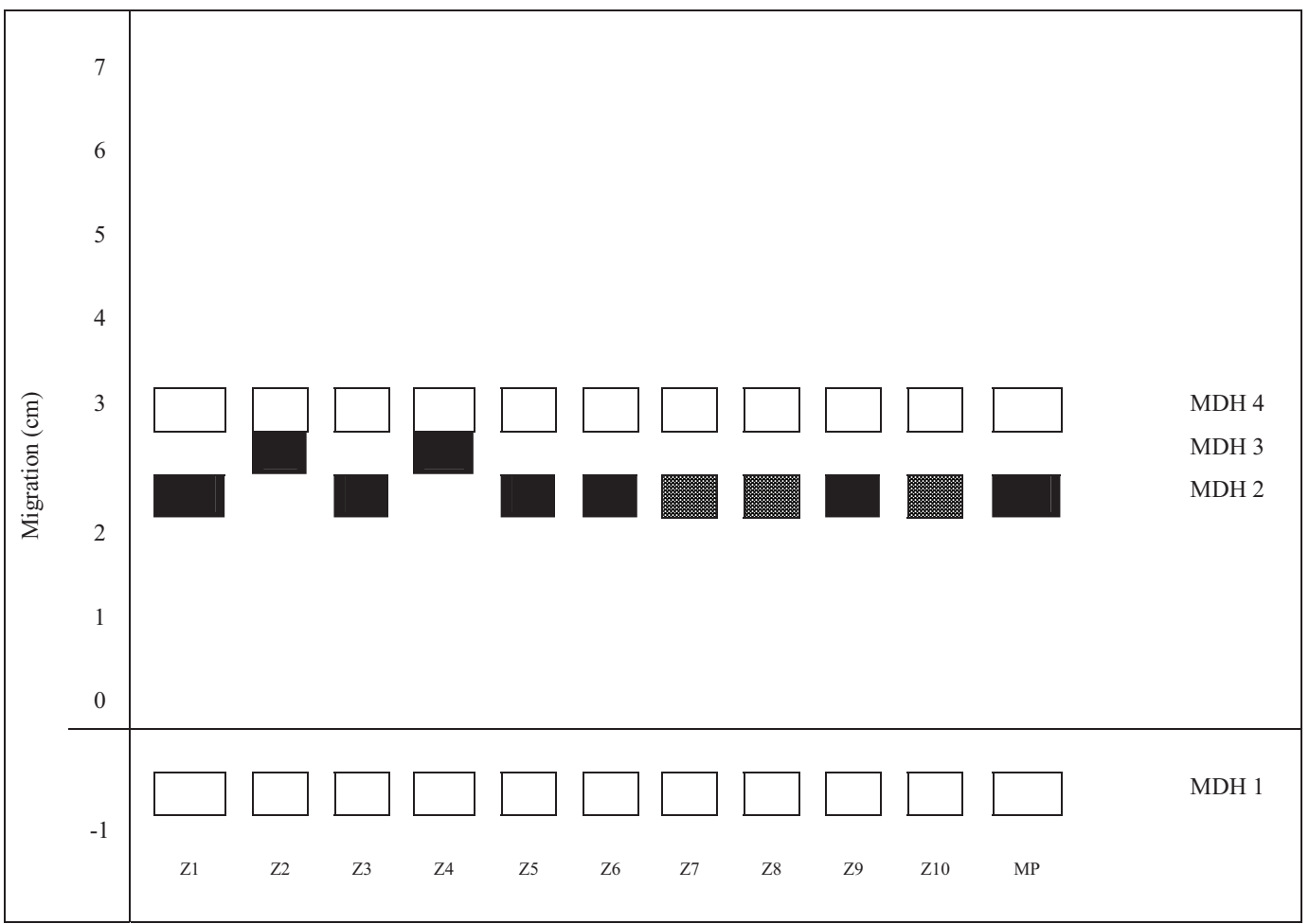

MALATO DEHYDROGENASE

Weak Band

Medium Band

Strong Band

Achromatic Band

Figure 4. Schematic representation of the zymograms of the Acid phosphatase and Malato dehydrogenase isoenzyme systems from micropropagated plants derived from zygotic embryos (Z) and from the matrix plant (MP) of Heliconia bihai (L.) L. cv. Lobster Claw Two. 


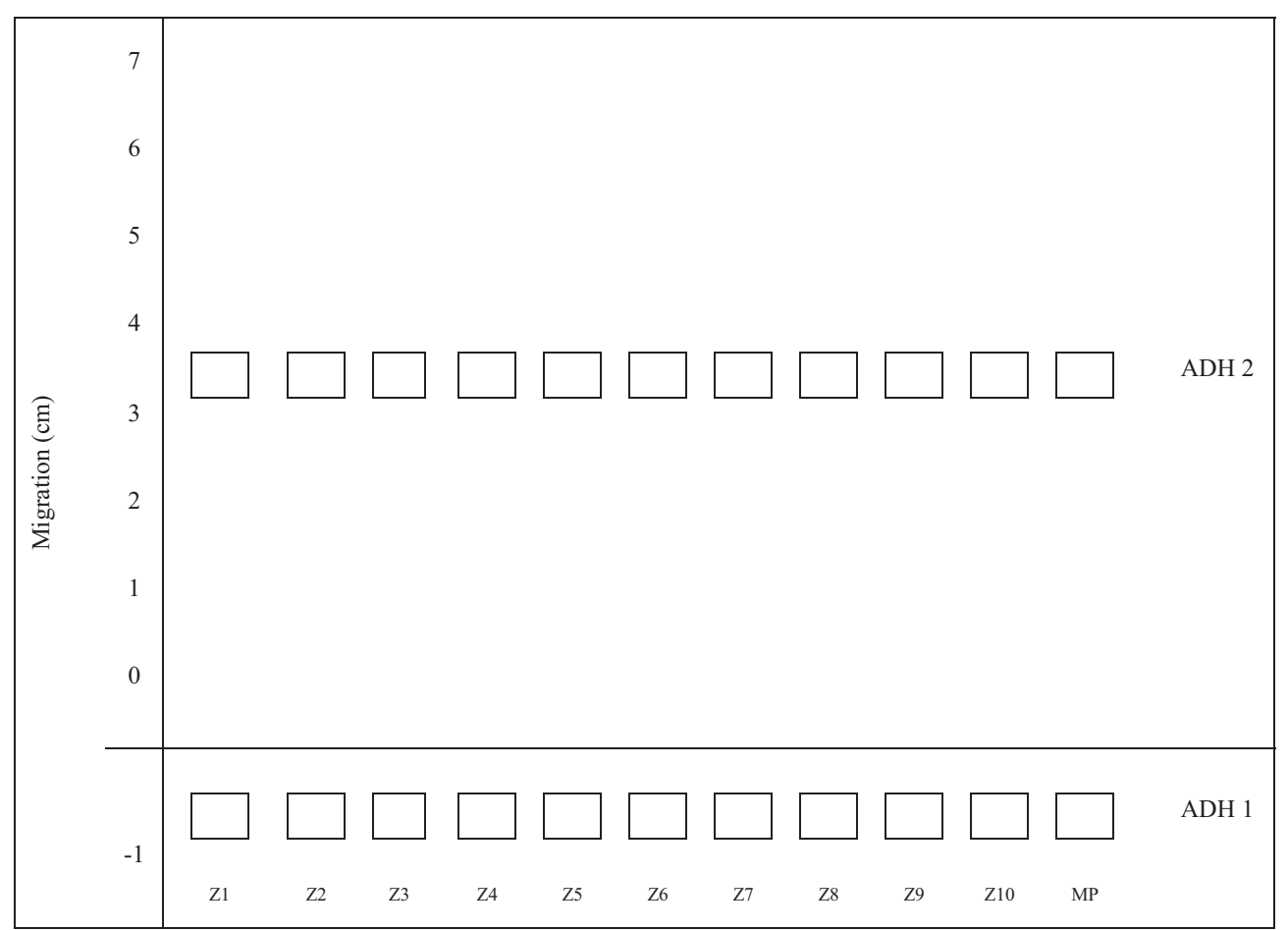

ALCOHOL DEHYDROGENASE

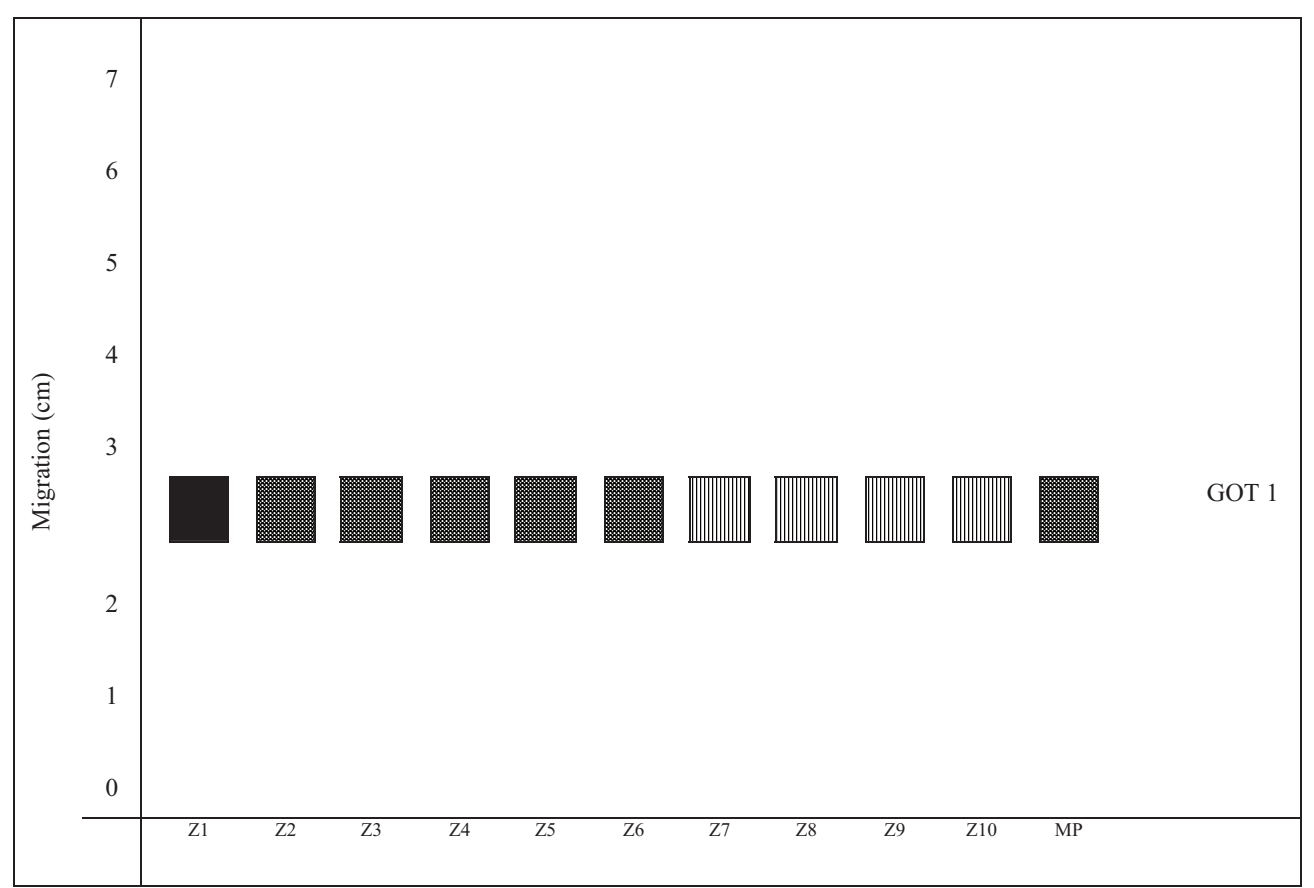

GLUTAMATE OXALOACETATE TRANSAMINASE

Weak Band

Medium Band

Strong Band

Achromatic Band

Figure 5. Schematic representation of the zymograms of the Alcohol dehydrogenase and Glutamate Oxaloacetate Transaminase isoenzyme systems from micropropagated plants derived from zygotic embryos (Z) and from the matrix plant (MP) of Heliconia bihai (L.) L. cv. Lobster Claw Two. 
systems, the results of the present work indicate the necessity of checking for genetic alterations based on DNA polymorphism in order to be able to recommend the use of zygotic embryos as explant sources for micropropagation.

\section{Acknowledgements}

The authors would like to thank Prof. Isabelle Meunier of the Universidade Federal Rural de Pernambuco (UFRPE) for her help in performing the statistical analyses, Prof. Luiza Semem Martins of UFRPE for aiding in the isoenzyme analyses, as well as the Banco do Nordeste do Brasil (BNB) and CAPES (Coordenação de Aperpeiçoamento Pessoal do Ensino Superior) for their financial support in preparing this study.

\section{References}

Alves, J.M.C.; Sihachakr, D.; Allot, M. Tizroutine, S.; Mussio, I. Servaes, A. \& Ducreux, G. 1994. Isozyme modifications and plant regeneration through somatic embryogenesis in sweet potato (Ipomoea batatas (1.) Lam.). Plant Cell Reports 13: 437-441.

Atehortua, L.; Urrea, A.L.; Gil, U.; Mora, B.; Valencia, C.; Corrales, M.; Carmona, A. \& Vallejo, A. 1999. Heliconia Tissue Culture. Bulletin of Heliconia Society International 9: 16-17.

Bridgen, M.P. 1994. Review of plant embryo culture. HortScience 29: 1243-1246.

Chu, I.Y.E. 1985. The application of tissue culture to plant improvement and propagation in the ornamental horticulture industry, p.15-35. In: Zimmermman, R. H.; Griesbach, R. J.; Hammerschlag, F. A.; Lawson, R. H. (Eds.). Tissue culture as a plant production system for horticultural crops. Martinus Nijhoff Publishers: 15-135.

Criley, R.A. 1989. Development of Heliconia and Alpinia in Hawaii: cultivar selection and culture. Acta Horticulturae 246: 247-258.

Criley, R.A. \& Broschat, T.K. 1992. Heliconia: botany and horticulture of a new floral crop. Horticultural Reviews 14. 55p.

Cousineau, J.C. \& Dounelly D.J. 1989. Identification of raspberry cultivars in vivo and in vitro using isozymes analysis. Hortscience 24: 490-492.

Dias, M.A. \& Rodrigues, P.H.V. 2001. Fontes de explantes e contaminantes isolados em cultivo in vitro de helicônia. Revista Brasileira de Horticultura Ornamental 7: 165-168.

Evans, D.A.; Sharp, W.R. \& Medina Filho, H.P. 1984. Somaclonal and gametoclonal variation. American Journal Botanical 71: 759-774.

Feuser, S.; Meler, K.; Daquinta, M. \& Guerra, M.P. 2003. Genotypic fidelity of micropropagated pineapple (Ananas comosus) plantlets assessed by isoenzyme and RAPD markers. Plant Cell, Tissue and Organ Culture 72: 221-227.

Freitas, N.S.A.; Burity, H.A.; Bezerra, J.E.F. \& Silva, M.V. 1995. Caracterização de clones de acerola (Malpighia glabra L.) através dos sistemas isoenzimáticos peroxidase-esterase. Pesquisa Agropecuária Brasileira 30: 1453-1457.

Gollagunta, V.; Adelberg, J.W.; Rieck, J. \& Rajapakse, N. 2004. Sucrose concentration in liquid media affects soluble carbohydrates, biomass and storage quality of micropropagated hosta. Plant Cell, Tissue and Organ Culture 77: 125-131.

Grattapaglia, D. \& Machado, M.A. 1998. Micropropagação. In: Torres, A.C.; Caldas, L.S.; Buso, J.A. Cultura de tecidos e transformaçãa de plantas. v.1. Brasília, EMBRAPA-SPI/EMBRAPA-CNPH. 183-260.

Hu, C.Y. \& Ferreira, A.G. 1998. Cultura de Embriões. In: Torres, A.C.; Caldas, L.S.; Buso. J.A. (Eds.). Cultura de tecidos e transformação genética de plantas. Brasília, EMBRAPA-SPI/CNPH. 371-393.

Ibraflor. 2001. Informativo IBRAFLOR. v.23. March. Ano 7.

Jarret, R.L. \& Litz, R.E. 1986. Isoenzymes as genetic markers in bananas and plantains. Euphytica 35: 539-549.

Johansen, D.A. 1940. Plant microtechnique. New York, McGraw-Hill.

Lamb, C.R.C.; Milach, S.C.K.; Pasqual, G. \& Barro, R.S. 2002. Embriogênese somática e regeneração de plantas a partir de embrião maduro de aveia. Pesquisa Agropecuária Brasileira 37: 123-130.

Llano-Agudelo, B. E.; Gozalez-Rosas, H. \& Salazar-Garcia. 1995. In vitro culture of mature avocado embryos. Fruits 1: 59-64.

Ledo, A.S.; Lameira, O.A.; Benbadis, A.K.; Menezes, I.C.; Ledo, C.A.S. \& Oliveira, M.S.P. 2001. Cultura in vitro de embriões zigóticos de açaizeiro. Revista Brasileira de Fruticultura 23: 468-472.

Ledo, A.S.; Gomes, K.K.P.; Barboza, S.B.S.C.; Vieira, G.S.S.; Tupinambá, E.A. \& Aragão, W.M. 2007. Cultivo in vitro de embriões zigóticos e aclimatização de plântulas de coqueiro-anão. Pesquisa Agropecuária Brasileira 42: 147-154.

Martini, P.C.; Willadino, L.; Alves, G.D. \& Donato, V.M.T.S. 2001. Propagação de orquídea Gongora quinquenervis por semeadura in vitro. Pesquisa Agropecuária Brasileira 36: 1319-1324.

Murashige, T. \& Skoog, F. 1962. Arevised medium for rapid growth and bioassays with tobacco tissue culture. Physiologia Plantarum 15: 473-497.

Nathan, M.S.; Goh, C.J. \& Kumar, P.P. 1992. In vitro propagation of Heliconia psittacorum by bud culture. Hortscience 27: 450-452.

Oliveira, R.P.; Silveira, D.G. \& Silva, S.O. 2001. Concentração de BAP e a eficiência de micropropagação de bananeira tetraplóide (Grupo AAAB). Scientia Agrícola 58: 73-78.

Paiva, W.O. 1998. Cultura de helicônias. Fortaleza, EMBRAPA-CNPAT (Circular técnica, 2)

Paiva, P.D.O.; Paiva, R.; Pasqual, M. \& Paiva, L.V. 2004. Estabelecimento in vitro de Estrelícia (Strelitzia reginae Banks). Ciência e Agrotecnologia 28: 1031-1037.

Pehu, E.; Gassman, C. Veilleux, R. \& Kalb, T. 1986. Changes in isozyme patterns and ultrastructure of callus tissue of Solanum phureja during regeneration. HortScience 21: 251.

Pereira, J.E.S.; Maciel, T.M.S.; Costa, F.H.S. \& Pereira, M.A.A. 2006. Germinação in vitro de embriões zigóticos de murmuru (Astrocaryum ulei). Ciência e Agrotecnologia 30: 251-256.

Poulik, M.D. 1957. Starch gel electrophoresis in a discontinuous system buffers. Nature 180:1477-1479.

Rani, V. \& Raina, S.N. 2000. Genetic fidelity of organized meristem-derived micropropagated plants: A critical reappraisal. In Vitro Cellular and Development Biology of Plant 36: 319-330.

Rojas, R.; Cuba, M.; Martínez, M.; García, D. \& Montes, S. 1996. Influencia de diferentes fuentes de carbono en la germinación y el desarrollo de embriones de Coffea arabica variedade 9722. Cultivos Tropicales 17: 82-84.

Royo, J.B.; Miranda, S.; Itoiz, R. \& Chocarro, A. 1994. Caracterización de variedades de vid (Vitis vinifera L.) mediante marcadores isoenzimáticos. Viticultura Enologia Professional 34: 20-28.

Sato, A.Y.; Nannetti, D.C.; Pinto, J.E.B.P.; Siqueira, J.O. \& Blank, M.F.A. 1999. Fungos micorrízicos-arbusculares no desenvolvimento de mudas de helicônia e gérbera micropropagadas. Horticultura Brasileira 17: 25-28.

Sawazaki, H.; Pommer, C.V.; Passos, I.R.S.; Terra, M.M. \& Pires, E.J.P. 1996. Identificação de parentais e híbridos entre Vitis vinifera e Vitis rotundifolia utilizando polimorfismo enzimático e marcador RAPD. Bragantia 55: 221-230.

Scandalios, J.G. 1969. Genetic control of multiple molecular forms of enzymes in plants: a review. Biochemical Genetics 3: 33-39.

Smith, M.K. 1988. A review of factors influencing the genetic stability of micropropagated bananas. Fruits 43: 219-223.

Taiz, L. \& Zeiger, E. 2004. Fisiologia Vegetal. 3 ed. Porto Alegre, Artmed.

Taylor, P.W.J.; Geijskes, J.R.; Ko, H.L.; Fraser, T.A.; Henry, R.J. \& Birch, R.G. 1995. Sensitivity of random amplified polymorphic DNA analysis to detect genetic change in sugarcane during tissue culture. Theoretical Applied Genetic 90:1169-1173.

Ulisses, C.; Camara, T.R.; Willadino, L.; Albuquerque, C.C.; Martins, L.S.S. \& Freitas, N.S.A. 2002. Caracterização isoenzimática de clones de bananeira nanicão submetidos à salinidade. Revista Brasileira de Engenharia Agrícola e Ambiental 6: 358-361.

Yokoo, E.Y.; Ramos, L.C.S. \& Bovi, M.L.A. 1992. Cultura de tecidos de híbridos e espécies de palmiteiro no Instituto Agronômico. Campinas, IAC. (Boletim científico, 25). 